\title{
FONEM SEGMENTAL BAHASA KANUM BARKARI
}

\section{SEGMENTAL PHONEMES OF KANUM BARKARI LANGUAGE}

\author{
Siti Masitha Iribaram \\ Balai Bahasa Provinsi Papua dan Provinsi Papua Barat \\ Jalan Yoka, Waena, Distrik Heram, Kota Jayapura, Papua \\ Ponsel 081344074515, Pos-el: sitha.iribaram@yahoo.com
}

\begin{abstract}
The purpose of this research is to describe the segmental phonemes of Kanum Barkari language. This language is located at territorial border between Indonesia and Papua New Guini. Kanum Barkari language is one of vernacular language spoken by people in Kondo village at Merauke Regency, Papua. This research uses descriptive method by using three stages; collecting, analyzing, and presenting data. Data analysis has been done after the collected data is classified. The analysis uses a distributional method. The results show that Kanum Barkari language has 16 consonant phonemes,

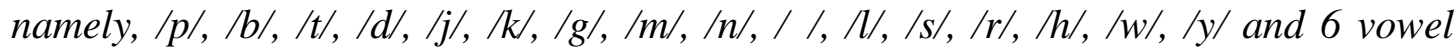
phonemes, /a/, / $/ /, / \mathrm{l} /$, /e/, / $/ \epsilon /$ dan $/ o /$.
\end{abstract}

Keywords: phonemes, segmental, consonant, vowel

\begin{abstract}
Abstrak
Tulisan ini membicarakan fonem segmental bahasa Kanum Barkari. Bahasa Kanum Barkari terletak di wilayah perbatasan Indonesia dengan Papua New Guini. Bahasa Kanum Barkari merupakan salah satu bahasa daerah yang ada di Papua yang dituturkan oleh masyarakat di Kampung Kondo, Kabupaten Merauke. Penelitian ini menggunakan metode deskriptif dengan tiga tahapan, yaitu tahap penyediaan data, tahap analisis data, dan tahap penyajian hasil analisis data. Analisis data dilaksanakan sesudah data yang terjaring diklasifikasikan. Analisis yang diterapkan menggunakan metode distribusional. Hasil kajian menunjukkan bahwa bahasa Kanum Barkari memiliki 16 buah fonem konsonan, yaitu /p/, /b/, /t/, /d/, /j/, /k/, /g/, /m/, /n/, /g/, /l/, /s/, /r/, /h/, /w/, /y/ dan 6 buah fonem vokal, yaitu /a/, /i/, /u/, /e/, /e/, dan /o/.
\end{abstract}

Kata kunci: fonem, segmental, konsonan, vokal

\section{Pendahuluan}

Indonesia merupakan bangsa yang kaya akan bahasa. Keberagaman bahasa yang tumbuh dan berkembang di tengah masyarakat merupakan indikator bahwa Indonesia memiliki keragaman suku, agama, budaya, sosial, ekonomi, dan geografi. Bahasa yang digunakan oleh suatu komunitas merupakan refleksi dari totalitas kebudayaan masyarakat itu.
Totalitas kebudayaan seperti yang dipaparkan di atas, tentu mencakup segala sisi kehidupan manusia.

Adanya perbedaan bahasa, secara spekulatif dapat dikatakan terdapat pula perbedaan budaya. Sebaliknya, adanya persamaan bahasa secara spekulatif pula dapat dikatakan terdapat persamaan budaya. Kesamaan bahasa yang dibarengi kesamaan budaya, jika ditinjau 
dari kehidupan sosial suatu komunitas akan banyak membawa kebaikan, karena setiap individu akan merasa sama dalam segala sisi kehidupannya dengan individu yang lain. Sebaliknya, perbedaan bahasa yang dibarengi perbedaan budaya, jika ditinjau dari kehidupan sosial suatu komunitas sangat rentan terhadap perselisihan dan perpecahan, karena individu pada suatu komunitas akan merasa lebih dibandingkan dengan individu komunitas lainnya.

Bahasa daerah memiliki tempat yang sangat penting di antara berbagai jenis kebudayaan daerah suatu kelompok etnis. Hal ini disebabkan bahasa daerah selain mengemban fungsi sebagai alat komunikasi antarmasyarakat daerah, juga berfungsi sebagai alat atau media pengembangan kebudayaan daerah itu, yang biasanya berlangsung secara lisan. Oleh sebab itu, bahasa daerah perlu diteliti sebagai upaya untuk mengantisipasi kemungkinan kepunahannya. Hal ini bisa saja terjadi, sebab bahasa itu terus-menerus berubah. Jika perubahan-perubahan itu dibiarkan begitu saja, maka cepat atau lambat akan sampai ke titik kepunahan. Dengan demikian, berarti kita telah kehilangan sebuah kebudayaan nasional yang sangat tinggi nilainya.

Kehilangan bahasa berarti kehilangan jati diri. Suku bangsa menjadi kabur apabila tidak ada bahasa yang menjadi ciri identitasnya. Oleh karena itu, adalah penting untuk dilakukan penelitian bahasa daerah. Penelitian bahasa daerah juga merupakan upaya pendokumentasian bahasa daerah tersebut, sehingga kelak pada masa yang akan datang masih tetap dapat dinikmati oleh generasi mendatang sebelum ia punah. Penelitian bahasa daerah berguna pula untuk pengembangan bahasa nasional karena kosakata bahasa nasional dapat dikembangkan dari bahasa daerah. Dari hasil penelitian struktur dan kosakata bahasa, dapat pula diperbandingkan bahasa-bahasa yang dapat mengungkapkan sejarah atau asalusul suatu suku.

Dengan adanya rekaman terhadap struktur dan kosakata suatu bahasa, orang lain lebih gampang belajar bahasa itu dan penutur asli belajar bahasa Indonesia lebih mudah dengan melihat dokumen kosakatanya. Keberadaan dokumen ini mempermudah penyampaian informasi kepada penutur asli bahasa itu, seperti informasi kesehatan, pertanian, perikanan, dan lain-lain dalam bahasa mereka.

Bahasa Kanum Barkari, merupakan salah satu bahasa daerah yang dipakai oleh penutur yang tinggal di Distrik Naukenjerai, Kabupaten Merauke, Provinsi Papua. Bahasa-bahasa daerah yang terdapat di Papua, yang memiliki kedudukan dan fungsi yang sama dengan bahasa daerah lain di Indonesia. Oleh sebab itu, patut mendapat prioritas dan perhatian yang sama dengan bahasa-bahasa daerah lain. Bahasa ini digunakan oleh kelompok masyarakat yang tinggal di Kampung Kondo. Adapun jumlah penuturnya kurang lebih 250 orang.

Bahasa Kanum Barkari terletak di wilayah perbatasan Indonesia dengan Papua New Guini. Sebagai wilayah perbatasan penduduk Kampung Kondo dengan tangan terbuka dan toleransi yang tinggi dapat menerima keberadaan sukusuku lain yang bermukim di Kampung Kondo. Dengan demikian, bahasa yang digunakan dalam pergaulan sehari-hari adalah bahasa Indonesia. Bahasa Kanum Barkari hanya digunakan dalam lingkungan keluarga. Tim Pemetaan dan Kekerabatan Bahasa-Bahasa Daerah di Indonesia, Badan Pengembangan dan Pembinaan Bahasa pada tahun 2014 mendokumentasikan bahasa Kanum Barkari. SIL (2006: 42) mengatakan bahwa di wilayah perbatasan Distrik 
Sota, Kabupaten Merauke dengan Negara Papua New Guini terdapat bahasa Kanum Sota, Kanum Badi, Kanum Smarky, dan Kanum Ngkalembu dalam klasifikasi kelas Trans-Nugini, TransFly-Sungai Bulaka dan hulu Sungai Maro. Menurut pengakuan penduduk Kampung Kondo bahasa mereka berbeda dengan bahasa Kanum Sota, Kanum Badi, Kanum Smarky, dan Kanum Ngkalembu. Fam/klen/marga penduduk Kampung Kondo, yaitu Mbanggu, Mayua, dan Sangra. Fam/klen/marga penduduk Kampung Kondo berbeda dengan marga penutur bahasa Kanum Sota, Kanum Badi, Kanum Smarky, dan Kanum Ngkalembu. Kelima bahasa tersebut berada dalam daerah perbatasan dengan negara Papua New Guini.

Mengacu pada uraian di atas, dianggap sangat perlu untuk meneliti struktur bahasa Kanum Barkari, terutama bidang fonologi, khususnya fonemfonem segmental. Fonologi sebagai bidang yang berkonsentrasi dalam deskripsi dan analisis bunyi-bunyi ujar. Hasil kerja fonologi berguna bahkan sering dimanfaatkan oleh cabang-cabang linguistik yang lain, baik linguistik teoretis maupun terapan. Misalnya morfologi, sintaksis, semantik, leksikologi, dialektologi, pengajaran bahasa, dan psikolinguistik.

Tulisan ini bertujuan mengetahui (1) bagaimana sistem bunyi bahasa Kanum Barkari, (2) jumlah fonem bahasa Kanum Barkari, (3) fonem-fonem vokal dan konsonan bahasa Kanum Barkari, (4) bagaimana distribusi fonem-fonem bahasa Kanum Barkari, dan (5) bagaimana pola suku kata bahasa Kanum Barkari.

\section{Landasan Teori}

Fonologi adalah bagian tata bahasa atau bidang ilmu bahasa yang menganalisis bunyi bahasa secara umum. Istilah fonologi berasal dari gabungan kata
Yunani fon berarti 'bunyi' dan $\log i$ berarti 'ilmu'. Sebagai bidang yang berkonsentrasi dalam deskripsi dan analisis bunyi-bunyi ujar, hasil kerja fonologi berguna bahkan sering dimanfaatkan oleh cabang-cabang linguistik yang lain, baik linguistik teoretis maupun terapan. Misalnya morfologi, sintaksis, semantik, leksikologi, dialektologi, pengajaran bahasa, dan psikolinguistik (Muslich, 2010: 2). Sementara itu, Kridalaksana (2008: 62) mengemukakan fonologi adalah bidang dalam linguistik yang menyelidiki bunyi-bunyi bahasa menurut fungsinya. Fonologi sangat bermanfaat dalam penyusunan ejaan bahasa. Ejaan adalah peraturan penggambaran atau pelambangan bunyi ujar suatu bahasa.

Analisis fonologi mencakup dua tataran, yaitu fonetik dan fonemik. Satuan bunyi (fon) dibicarakan dalam tataran fonetik, sedangkan satuan fonem dibicarakan dalam tataran fonemik (Lapoliwa,1980: 1). Bloomfield (1933: 78) mendefinisikan fonem sebagai unit bunyi terkecil yang dapat membedakan arti.

Menurut Samsuri (1982: 130) bunyi-bunyi bahasa yang secara fonetis mirip harus digolongkan ke dalam kelas bunyi atau fonem yang berbeda apabila terdapat pertentangan di dalam lingkungan yang sama atau mirip. Hipotesis ini dapat ditunjukkan dengan pasangan minimal yang bertujuan untuk menciptakan kekontrasan. Jika ada dua bunyi yang tidak dapat saling menggantikan dalam kerangka yang sama pasangan yang mendekati dapat digunakan. Sementara itu, bunyi yang secara fonetis mirip dan terdapat di dalam distribusi yang komplementer harus dimasukkan ke dalam fonem yang sama.

Secara garis besar bunyi bahasa dapat dikelompokkan menjadi dua, yaitu bunyi segmental dan bunyi 
suprasegmental. Bunyi segmental dapat dikelompokkan menjadi bunyi kontoid dan bunyi vokoid. Bunyi kontoid atau konsonan dapat diklasifikasikan menjadi beberapa bagian berdasarkan parameter (1) daerah artikulasi, (2) cara artikulasi, (3) jalan atau pintu keluar udara, (4) keadaan pita suara, (5) mekanisme arus udara, dan (6) arah arus udara (Lapoliwa, 1980: 30). Sementara itu, parameter bunyi vokoid atau vokal, yaitu (1) tinggi lidah (sumbu horizontal), (2) struktur, (3) bagian lidah yang dinaikkan (sumbu horizontal), dan (4) bentuk bibir saat melafalkannya (Lapoliwa, 1980: 35).

Bunyi vokoid maupun kontoid ada yang diucapkan secara rangkap. Perangkapan bunyi ini ditandai dengan satuan hembusan udara ketika bunyi itu diucapkan. Perangkapan bunyi vokoid disebut diftong, sedangkan perangkapan pada kontoid disebut kluster. Dalam praktiknya lebih lanjut, diftong ini ada dua macam. Diftong menurun yaitu diftong yang ketika perangkapan bunyi vokoid diucapkan, vokoid pertama bersonoritas, sedangkan vokoid kedua kurang bersonoritas bahkan mengarah ke bunyi nonvokoid. Diftong menurun, misalkan terdapat pada kata pulau, harimau, sampai, ramai, dan lain-lain. Diftong menaik adalah diftong yang ketika perangkapan bunyi vokoid itu diucapkan, vokoid pertama kurang dan mengarah bunyi nonvokoid, sedangkan vokoid kedua menguat sonoritasnya (Muslich, 2010: 69-71).

Bunyi vokal, konsonan, dan semivokal dibedakan berdasarkan tempat dan bunyi artikulasinya. Vokal merupakan jenis bunyi bahasa yang ketika dihasilkan atau diproduksi, setelah arus ujar ke luar dari glotis tidak mendapat hambatan dari alat ucap, melainkan hanya diganggu oleh posisi lidah, baik vertikal maupun horizontal, dan bentuk mulut. Konsonan terjadi setelah bunyi arus ujar melewati pita suara diteruskan rongga mulut dengan mendapatkan hambatan dari artikulator aktif dan artikulator pasif. Sedangkan bunyi semivokal melalui proses pembentukan mula-mula secara vokal lalu diakhiri secara konsonan (Chaer, 2009: 32).

Sementara terkait perubahan bunyi, dibedakan menjadi dua, yaitu perubahan fonetis dan perubahan fonemis. Apabila perubahan itu tidak sampai membedakan makna atau mengubah identitas fonem, maka bunyi-bunyi tersebut masih merupakan alofon atau variasi bunyi dari fonem yang sama. Dengan kata lain, perubahan ini masih dalam lingkup perubahan fonetis. Tetapi, apabila perubahan bunyi itu sudah sampai berdampak pada pembedaan makna atau mengubah identitas fonem, maka bunyibunyi tersebut merupakan alofon dari fonem yang berbeda. Dengan kata lain, perubahan itu disebut sebagai perubahan fonemis.

Dalam kaitannya dengan fonemfonem yang terdapat dalam suatu bahasa, bahasa-bahasa yang ada di dunia ini semuanya memiliki kaidah tertentu dalam pengurutannya. Itulah sebabnya ada fonem-fonem tertentu yang mungkin berurutan dan ada pula fonem-fonem yang mungkin tidak berurutan. Berkaitan dengan kaidah-kaidah tertentu yang terdapat dalam suatu bahasa Hartman dan Stork (1972) menamai kaidah-kaidah tersebut dengan istilah fonotaktik. Fonotaktik adalah sistem penyusunan unit-unit linguistik secara berurutan yang khas. Batasan ini menjelaskan kepada kita bahwa selain fonem dalam suatu bahasa terdapat pula kaidah fonotaktik.

Berbicara tentang fonotaktik, Stetson dalam Suharyanto (2006: 31) mengatakan bahwa suku kata berhubungan dengan hentakan kegiatan antara kelompok urat-urat (denyut dada) sehingga pada suatu saat penutur menghasilkan suku kata sebagai getaran- 
getaran urat yang mandiri. Suku kata oleh Alwi (2000: 55) dikatakan adalah bagian kata yang diucapkan dalam suatu hembusan nafas dan umumnya terdiri atas beberapa fonem. Adapun deretan dua konsonan atau lebih yang tergolong dalam satu suku kata yang sama disebut gugus konsonan. Deretan dua konsonan atau lebih yang tergolong dalam suku kata yang berbeda disebut deret konsonan. Demikian pula dengan fonem vokal, deretan dua vokal yang tergolong dalam satu suku kata yang sama disebut gugus vokal atau diftong. Sementara itu, deretan dua vokal yang tergolong dalam suku kata yang berbeda disebut deret vokal.

\section{Metode dan Teknik}

Penelitian ini bersifat kualitatif dengan menggunakan metode deskriptif. Penelitian ini menggunakan tiga tahapan strategis yang dilakukan secara beruntun. Ketiga tahapan tersebut adalah tahap penyediaan data, tahap penganalisisan data, dan tahap penyajian hasil analisis data (Sudaryanto, 1993: 5). Penyediaan data penelitian ini menggunakan metode cakap dengan teknik pancing sebagai teknik dasar dan teknik cakap semuka sebagai teknik lanjutan I, teknik catat sebagai teknik lanjutan II, dan teknik rekam sebagai teknik lanjutan III (Sudaryanto, 1993: 137-139). Sementara itu, analisis data berdasarkan pada prosedur dan teknik analisis fonem, yaitu (1) mengidentifikasi dan mengklasifikasi data, (2) membuat peta fonetik, (3) mendaftar pasangan segmen yang dicurigai, (4) mendaftar segmensegmen yang tidak dicurigai, (5) mengontraskan secara bilateral dan multilateral, (6) mengontraskan secara distribusi komplementer,

mengontraskan dalam lingkungan analogis, dan (8) bunyi yang tersisa (secara fonetis) dianggap sebagai fonem tersendiri. Setelah data dianalisis hasilnya disajikan dengan metode formal (Sudaryanto, 1993: 145).

\section{Deskripsi Fonem Bahasa Kanum Barkari}

\subsection{Inventarisasi Bunyi}

Berdasarkan analisis data dapat diketahui bahwa bahasa Kanum Barkari memiliki dua puluh dua (22) bunyi konsonan dan empat belas (14) bunyi vokal. Kedua puluh dua bunyi konsonan tersebut adalah [p, b, t, d, j, k, g, m, n, y, l, s, r, h, ?, g:, r:, b:, l:,, w, dan y]. Sementara itu, keempat belas bunyi vokal itu adalah [a, a:, i, i:, u, u:, e, , є, є:, o, Ј, Ј:, dan o:]. Ciri-ciri artikulatoris bunyi konsonan dapat dilihat pada tabel 1 dan ciri-ciri artikulatoris bunyi vokal dapat dilihat pada tabel 2. Kedua puluh dua bunyi konsonan dan keempat belas bunyi vokal inilah yang menjadi dasar analisis dan pemerian fonem bahasa Kanum Barkari. 
Tabel 1. Bunyi Konsonan Kanum Barkari 1

\begin{tabular}{|c|c|c|c|c|c|c|c|}
\hline $\begin{array}{l}\text { Daerah } \\
\text { artikulasi }\end{array}$ & $\begin{array}{l}\frac{3}{0} \\
\frac{0}{0}\end{array}$ & 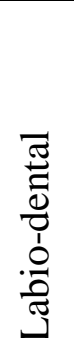 & 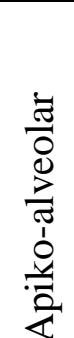 & 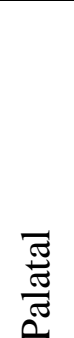 & $\begin{array}{l}\frac{\bar{t}}{0} \\
0 \\
0 \\
0 \\
0 \\
0 \\
0\end{array}$ & 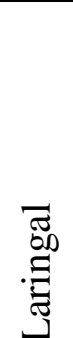 & 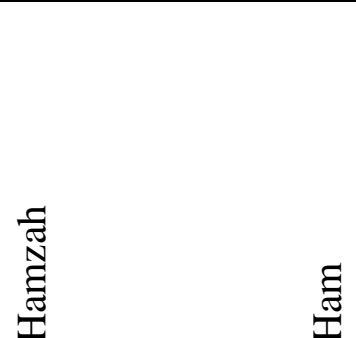 \\
\hline $\begin{array}{r}\text { Hambat letup Tbs } \\
\text { Bs }\end{array}$ & $\begin{array}{l}\mathrm{b} \\
\mathrm{b}:\end{array}$ & & $\mathrm{t}$ & & $\begin{array}{l}\mathrm{k} \\
\mathrm{g} \\
\mathrm{g}:\end{array}$ & & \\
\hline $\begin{array}{ll}\text { Afrikat } & \text { Tbs } \\
& \text { Bs } \\
\end{array}$ & & & & j & & & \\
\hline Sengau & $\mathrm{m}$ & & $\mathrm{n}$ & & $\mathrm{n}$ & & \\
\hline Sampingan Bs & & & $\begin{array}{l}1 \\
1:\end{array}$ & & & & \\
\hline Geseran $\quad$ Tbs & & & $\mathrm{s}$ & & & $\mathrm{h}$ & \\
\hline Geletar & & & $\begin{array}{l}\mathrm{r} \\
\mathrm{r}:\end{array}$ & & & & \\
\hline Semi-vokal Bs & $\mathrm{w}$ & & & $\mathrm{y}$ & & & \\
\hline
\end{tabular}

Keterangan: $\mathrm{Tbs}=$ tidak bersuara

Bs = bersuara

Tabel 2. Bunyi Vokal Kanum Barkari

\begin{tabular}{|c|c|c|c|c|c|c|}
\hline & \multicolumn{2}{|c|}{ Depan } & \multicolumn{2}{|c|}{ Tengah } & \multicolumn{2}{|c|}{ Belakang } \\
\hline & TBL & BL & TBL & BL & TBL & BL \\
\hline Tinggi atas & $\begin{array}{l}\text { i } \\
\mathrm{i}:\end{array}$ & & & & & $\begin{array}{l}\mathrm{u} \\
\mathrm{u}:\end{array}$ \\
\hline bawah & & & & & & \\
\hline atas & $\begin{array}{c}\epsilon \\
\epsilon:\end{array}$ & & $\partial$ & & & $\begin{array}{c}\text { O } \\
\text { o: }\end{array}$ \\
\hline bawah & $\mathrm{e}$ & & & & & $\begin{array}{l}\text { ว } \\
\text { Ј: }\end{array}$ \\
\hline Rendah & & & $\begin{array}{c}\mathrm{a} \\
\mathrm{a}:\end{array}$ & & & \\
\hline
\end{tabular}

Keterangan: $\mathrm{Tbl}=$ tak bulat

$\mathrm{Bl}=$ bulat 
4.2 Kontras dan Variannya

\subsubsection{Kontras Konsonan Variannya}

Hasil analisis data menunjukkan bahwa bahasa Kanum Barkari memiliki enam belas (16) buah fonem konsonan.
Keenam belas fonem tersebut adalah $/ \mathrm{p} /$, dan $/ \mathrm{b} /, / \mathrm{t} /, / \mathrm{d} /, / \mathrm{j} /, / \mathrm{k} /, / \mathrm{g} /, / \mathrm{m} /, / \mathrm{n} /, / \mathrm{l} /, / \mathrm{l} /, / \mathrm{s} /$, $/ \mathrm{r} /, / \mathrm{h} /, / \mathrm{w} /$, dan $/ \mathrm{y} /$. Keberadaan fonem konsonan tersebut dapat dibuktikan dari kontras yang terdapat pada tabel 3 berikut.

\section{Tabel 3. Kontras Fonem Konsonan Bahasa Kanum Barkari}

\begin{tabular}{|l|l|l|}
\hline No. & Kontras konsonan & Contoh \\
\hline 1. & $/ \mathrm{b} /<=>/ \mathrm{d} /$ & [bu:] 'engkau' $<=>$ [du:] 'bintang' \\
\hline 2. & $/ \mathrm{p} /<=>/ \mathrm{n} /$ & [pi] 'ia' $<=>$ [ni] 'kami' \\
\hline 3. & $/ \mathrm{r} /<=>/ \mathrm{s} /$ & [ari] 'ayah' $<=>$ [asi] 'nenek' \\
\hline 4. & $/ \mathrm{r} /<=>/ \mathrm{t} /$ & [soro] 'gigit' $<=>$ [soto] 'potong' \\
\hline 5. & $/ \mathrm{y} /<=>/ \mathrm{w} /$ & [yowi] 'bulu' $<=>$ [wowi] 'mangga' \\
\hline 6. & $/ \mathrm{m} /<=>/ \mathrm{w} /$ & [dam] 'keranjang' $<=>$ [daw] 'tempat' \\
\hline 7. & $/ \mathrm{l} /<=>/ \mathrm{t} /$ & [petel] 'tangan' $<=>$ [peter] 'kepala desa' \\
\hline
\end{tabular}

Fonem /s/ dalam bahasa Kanum Barkari memiliki dua buah alofon, yaitu [s] dan [ ]. Fonem /s/ akan terealisasi menjadi [s] apabila berada pada posisi awal suku kata terbuka dan diikuti oleh vokal depan, sementara fonem /s/ akan terealisasi menjadi [ ] apabila berada di luar lingkungan tersebut, pada posisi suku kata tertutup dan berpola satu suku kata.

Fonem /k/ dalam bahasa Kanum Barkari memiliki dua buah alofon, yaitu [k] dan []. Fonem /k/ akan terealisasi menjadi [k] apabila berada pada posisi awal suku kata dan diikuti oleh vokal depan rendah, sementara fonem $/ \mathrm{k} /$ akan terealisasi menjadi [ ] apabila berada di luar lingkungan tersebut.

Fonem /r/ dalam bahasa Kanum Barkari memiliki dua buah alofon, yaitu [r] dan [r:]. Fonem /r/ akan terealisasi menjadi [r] apabila berada pada posisi awal dan akhir suku kata dan diikuti oleh vokal depan rendah, sementara fonem $/ \mathrm{r}$ / akan terealisasi menjadi [r:] apabila berada di luar lingkungan tersebut.

Fonem /g/ dalam bahasa Kanum Barkari memiliki dua buah alofon, yaitu [g] dan [g:]. Fonem /g/ akan terealisasi menjadi [g] apabila berada pada posisi awal dan diikuti oleh vokal depan rendah, sementara fonem /g/ akan terealisasi menjadi [g:] apabila berada di luar lingkungan tersebut.

Fonem /b/ dalam bahasa Kanum Barkari memiliki dua buah alofon, yaitu [b], dan [b:]. Fonem /b/ akan terealisasi menjadi [b] apabila berada pada suku kata terbuka yang mendapat tekanan dan suku kata tertutup, sedangkan fonem /b/ akan terealisasi menjadi [b:] apabila berada pada suku kata terbuka yang mendapat tekanan dan berada di luar lingkungan tersebut.

Fonem /1/ dalam bahasa Kanum Barkari memiliki dua buah alofon, yaitu [1] dan [1:]. Fonem /1/ akan terealisasi menjadi [1] apabila berada pada suku kata terbuka yang mendapat tekanan dan suku kata tertutup, sedangkab fonem /// akan terealisasi menjadi [1:] apabila berada pada suku kata terbuka yang mendapat tekanan dan berada di luar lingkungan tersebut.

\subsubsection{Kontras vokal dan variannya}

Bahasa Kanum Barkari memiliki enam buah fonem vokal. Keenam fonem tersebut adalah /a/, /i/, /u/, /e/, /€/, dan /o/. Keberadaan fonem vokal tersebut dapat 
dibuktikan dari kontras yang terdapat pada tabel 4 berikut.

Tabel 4. Kontras Fonem Vokal Bahasa Kanum Barkari

\begin{tabular}{|c|c|c|}
\hline No. & Kontras Vokal & Contoh \\
\hline 1. & /i/ $<=>/ \mathrm{o} /$ & [sindo] 'burung' $\Leftrightarrow=>$ [sondo] 'beri' \\
\hline 2. & $/ \mathrm{u} /<=>/ \mathrm{o} /$ & [yur] 'telur' $<=>$ [yor] 'tidur' \\
\hline 3. & /e/ $\Leftrightarrow>/ \epsilon /$ & [bel] 'pohon' $<=>$ [ber] 'dada' \\
\hline 4. & $/ \mathrm{a} /<=>/ \mathrm{e} /$ & [wal] 'burung hantu' $\Leftrightarrow=>$ [wel] 'hujan' \\
\hline 5. & $/ \mathrm{a} /<=>$ i $/$ & [ a] 'atap' $<=>$ [si] 'mata' \\
\hline
\end{tabular}

Fonem /o/ dalam bahasa Kanum Barkari memiliki empat buah alofon, yaitu [o], [o:], [०], dan [o:]. Fonem /o/ akan terealisasi menjadi [o] apabila berada pada suku kata terbuka yang tidak mendapat tekanan, fonem /o/ akan terealisasi menjadi [o:] apabila berada pada suku kata terbuka yang mendapat tekanan, fonem /o/ akan terealisasi menjadi [॰] apabila berada pada suku kata terbuka yang tidak mendapat tekanan, sementara fonem /o/ akan terealisasi menjadi [ว:] apabila berada di luar lingkungan tersebut.

Fonem /e/ dalam bahasa Kanum Barkari memiliki dua buah alofon, yaitu [e] dan [ə]. Fonem /e/ akan terealisasi menjadi [e] apabila berada pada suku kata terbuka yang mendapat tekanan. Fonem /e/ akan terealisasi menjadi [ə] apabila berada di luar lingkungan tersebut.

Fonem /i/ dalam bahasa Kanum Barkari memiliki dua buah alofon, yaitu [i] dan [i:]. Fonem /i/ akan terealisasi menjadi [i:] apabila berada pada suku terbuka yang tidak mendapat tekanan dan fonem /i/ akan terealisasi menjadi [i] apabila berada di luar lingkungan tersebut.

Fonem /u/ dalam bahasa Kanum Barkari memiliki dua buah alofon, yaitu [u] dan [u:]. Fonem /u/ akan terealisasi menjadi [u:] apabila berada pada suku terbuka yang tidak mendapat tekanan dan fonem /u/ akan terealisasi menjadi [u] apabila berada di luar lingkungan tersebut.

Fonem /a/ dalam bahasa Kanum Barkari memiliki dua buah alofon, yaitu [a] dan [a:]. Fonem /a/ akan terealisasi menjadi [a:] apabila berada pada suku terbuka yang tidak mendapat tekanan dan fonem /a/ akan terealisasi menjadi [a] apabila berada di luar lingkungan tersebut.

\subsection{Distribusi Fonem Bahasa Kanum Barkari}

\subsubsection{Distribusi Fonem Konsonan}

Berdasarkan analisis data, dapat diketahui bahwa dalam bahasa Kanum Barkari terdapat enam belas fonem konsonan. Dari keenam belas fonem konsonan tersebut, delapan fonem konsonan, yaitu $/ \mathrm{m} /, / \mathrm{n} /, / \mathrm{d} /, / \mathrm{l} /, / / /, / \mathrm{s} /$, $/ \mathrm{r} /$, dan $/ \mathrm{w} /$ berdistribusi lengkap, tujuh fonem konsonan, yaitu /p/, /b/, /t/, /j/, /k/, /g/, dan /y/ merupakan konsonan yang berdistribusi pada awal dan tengah kata, sementara konsonan /h/ hanya berdistribusi di akhir kata. Keberadaan distribusi fonem konsonan bahasa Kanum Barkari dapat dilihat pada tabel 5 berikut ini. 
Tabel 5. Distribusi Fonem Konsonan Bahasa Kanum Barkari

\begin{tabular}{|c|c|c|c|c|}
\hline \multirow{2}{*}{ Fonem } & \multicolumn{3}{|c|}{ Posisi } & \multirow{2}{*}{ Ket. } \\
\hline & Awal & Tengah & Akhir & \\
\hline$/ \mathrm{p} /$ & $\begin{array}{l}\text { [pəwal] 'abu' } \\
\text { [pakas] 'baik' } \\
\text { [pera] 'panas' }\end{array}$ & $\begin{array}{c}\text { [nəpa] 'anak' } \\
\text { [kəmpir] 'baring' } \\
\text { [yalpe] 'dua' }\end{array}$ & - & \\
\hline$/ \mathrm{b} /$ & $\begin{array}{l}\text { [buspayə] 'busuk' } \\
\text { [bumbu] 'buah' } \\
\text { [beg:e] 'dingin' }\end{array}$ & $\begin{array}{c}\text { [tub:e] 'batu' } \\
\text { [kəlbu] 'bengkak' } \\
\text { [mbat] 'gunung' }\end{array}$ & - & \\
\hline$/ \mathrm{m} /$ & $\begin{array}{l}\text { [mandeu] 'bulan' } \\
\text { [mayi] 'di mana' } \\
\text { [meri] 'orang }\end{array}$ & $\begin{array}{c}\text { [ əmju] 'dorong' } \\
\text { [kasamka] 'gosok' } \\
\text { [kami] 'duduk' }\end{array}$ & $\begin{array}{l}\text { [ aram] 'bunuh' } \\
\text { [yandəm] 'hati' } \\
\text { [kənom] 'minum' }\end{array}$ & \\
\hline$/ \mathrm{n} /$ & $\begin{array}{c}\text { [nowayi] 'datang' } \\
\text { [nipapu] 'kamu' } \\
\text { [namba] 'dari' }\end{array}$ & $\begin{array}{l}\text { [sindo] 'burung' } \\
\text { [kono] 'berjalan' } \\
\text { [dende] 'panjang', }\end{array}$ & $\begin{array}{c}\text { [wan] 'pikir' } \\
\text { [lamin] 'lidah' } \\
\text { [dən] 'urat' }\end{array}$ & \\
\hline$/ t /$ & $\begin{array}{l}\text { [teitau] 'belum' } \\
\text { [tua] 'pernah' } \\
\text { [takor] 'sembuh' }\end{array}$ & $\begin{array}{l}\text { [kJtu] 'henti' } \\
\text { [septu] 'angkat' } \\
\text { [yərta] 'ringan' }\end{array}$ & - & \\
\hline$/ \mathrm{d} /$ & $\begin{array}{l}\text { [doni] 'bisul' } \\
\text { [delkin] 'cecak' } \\
\text { [daw] 'wadah' }\end{array}$ & $\begin{array}{l}\text { [sindi] 'belek' } \\
\text { [konduyi] 'atas' } \\
\text { [kinda] 'cabai' }\end{array}$ & [bend] 'nanah' & \\
\hline$/ \mathrm{j} /$ & $\begin{array}{c}\text { [jikaka] 'elang' } \\
\text { [jawane] 'kepiting' }\end{array}$ & $\begin{array}{l}\text { [ əmju] 'dorong' } \\
\text { [yayiji] 'daging' } \\
\text { [kənjere] 'berat' }\end{array}$ & - & \\
\hline$/ \mathrm{k} /$ & $\begin{array}{c}\text { [kom] 'air' } \\
\text { [kari] 'dengar' } \\
\text { [katip] 'ikan' }\end{array}$ & $\begin{array}{c}\text { [walkam] 'garam' } \\
\text { [seriku] 'ikat' } \\
\text { [golki] 'ketiak' }\end{array}$ & - & \\
\hline$/ \mathrm{g} /$ & $\begin{array}{l}\text { [guwi] 'di sini' } \\
\text { [golki] 'ketiak' } \\
\text { [gənaykən] 'pipi' }\end{array}$ & $\begin{array}{l}\text { [ndogre] 'kodok' } \\
\text { [bəygi] 'miring' } \\
\text { [begande] 'istri' }\end{array}$ & - & \\
\hline$/ \mathrm{y} /$ & $\begin{array}{c}\text { [yomin] 'besar' } \\
\text { [ygawu] 'kulit' } \\
\text { [ygo] 'saya' }\end{array}$ & $\begin{array}{l}\text { [nəyka] 'adik' } \\
\text { [sitanga] 'alis' } \\
\text { [dangəti] 'siku' }\end{array}$ & $\begin{array}{l}\text { [noy] 'abang' } \\
\text { [kəyay] 'sagu' }\end{array}$ & \\
\hline$/ 1 /$ & $\begin{array}{c}\text { [lamin] 'lidah' } \\
\text { [lowo] 'ekor' }\end{array}$ & $\begin{array}{l}\text { [selbar] 'buang' } \\
\text { [kəlsum] 'turun' } \\
\text { [dalban] 'sedang', }\end{array}$ & $\begin{array}{l}\text { [kal] 'pikul' } \\
\text { [wel] 'hujan' } \\
\text { [pel] 'pohon' }\end{array}$ & \\
\hline$/ \mathrm{s} /$ & $\begin{array}{l}\text { [semir] 'gantung' } \\
\text { [sermi] 'hirup' } \\
\text { [suwəro] 'kulum' }\end{array}$ & $\begin{array}{c}\text { [isi] 'jarum' } \\
\text { [kəsebla] 'hutan' } \\
\text { [aser] 'empat' }\end{array}$ & $\begin{array}{l}\text { [pokos] 'sehat' } \\
\text { [pakas] 'baik' } \\
\text { [resres] 'jurang' }\end{array}$ & \\
\hline$/ \mathrm{r} /$ & [reyi] ‘siapa’ & [urkari] 'ladang' & [karkir] 'pusing' & \\
\hline
\end{tabular}




\begin{tabular}{|c|c|c|c|}
\hline & [resres] 'landai' & $\begin{array}{l}\text { [sermin] 'pelangi' } \\
\text { [sarwa] 'panggil' }\end{array}$ & $\begin{array}{l}\text { [wawor] 'timur' } \\
\text { [sekar] 'terima' }\end{array}$ \\
\hline$/ \mathrm{h} /$ & - & - & $\begin{array}{l}\text { [bah] 'nyamuk' } \\
\text { [kantuh] 'atas' } \\
\text { [məteh] 'bawah' }\end{array}$ \\
\hline$/ \mathrm{w} /$ & $\begin{array}{l}\text { [wilir] 'alir' } \\
\text { [wəl] 'hujan' } \\
\text { [wala] 'laut' }\end{array}$ & $\begin{array}{l}\text { [kuwə] 'angin' } \\
\text { [duwal] 'anjing' } \\
\text { [soliwo] 'gali' }\end{array}$ & $\begin{array}{l}\text { [tow] 'sampan' } \\
\text { [daw] 'wadah' } \\
\text { [sew] 'rumput' }\end{array}$ \\
\hline$/ y /$ & $\begin{array}{c}\text { [yajibel] 'binatang' } \\
\text { [yalpe] 'dua' } \\
\text { [yu] 'nama' }\end{array}$ & $\begin{array}{l}\text { [yuyui] 'tengah' } \\
\text { [nowayi] 'datang' } \\
\text { [sepayi] 'pegang' }\end{array}$ & - \\
\hline
\end{tabular}

\subsubsection{Distribusi Fonem Vokal}

Berdasarkan analisis data, dapat diketahui bahwa dalam bahasa Kanum Barkari terdapat enam fonem vokal. Dari enam fonem vokal tersebut, lima fonem vokal, yaitu /a/, /u/, /i/, /o/, dan /e/ berdistribusi lengkap, sementara satu fonem vokal lainnya, yaitu /€/ berdistribusi pada tengah dan akhir kata. Keberadaan distribusi fonem vokal bahasa Kanum Barkari dapat dilihat pada tabel 6 berikut ini.

Tabel 6. Distribusi FonemVokal Bahasa Kanum Barkari

\begin{tabular}{|c|c|c|c|c|}
\hline \multirow[t]{2}{*}{ Fonem } & \multicolumn{3}{|c|}{ Posisi } & \multirow[t]{2}{*}{ Ket. } \\
\hline & Awal & Tengah & Akhir & \\
\hline$/ \mathrm{a} /$ & $\begin{array}{l}\text { [ari] 'ayah' } \\
\text { [aser] 'empat' } \\
\text { [asi] 'nenek' }\end{array}$ & $\begin{array}{l}\text { [tayinu] 'baru' } \\
\text { [ndari] 'darah' } \\
\text { [kami] 'duduk' }\end{array}$ & $\begin{array}{l}\text { [kuwiya] 'buru' } \\
\text { [wala] 'laut' } \\
\text { [kəra] 'muntah' }\end{array}$ & \\
\hline /i/ & $\begin{array}{l}\text { [iyəre] 'bakul' } \\
\text { [isi] 'jarum' }\end{array}$ & $\begin{array}{c}\text { [mayino] 'kapan' } \\
\text { [seriro] 'garuk' } \\
\text { [meyitro] 'tungku' }\end{array}$ & $\begin{array}{c}\text { [meyi] 'api' } \\
\text { [bəlani] 'buruk' } \\
\text { [kari] 'dengar' }\end{array}$ & \\
\hline$/ \mathrm{u} /$ & $\begin{array}{c}\text { [unaikom] 'minuman' } \\
\text { [urkari] 'ladang' }\end{array}$ & $\begin{array}{c}\text { [sun] 'asap' } \\
\text { [tuni] 'perut' } \\
\text { [tuti] 'sungai' }\end{array}$ & $\begin{array}{l}\text { [toptu] 'apung' } \\
{[\text { malku] 'benih', }} \\
\text { [nipapu] 'kamu' }\end{array}$ & \\
\hline /e/ & $\begin{array}{c}\text { [əmpi] 'satu' } \\
\text { [elibaba] 'lubuk' }\end{array}$ & $\begin{array}{l}\text { [serumpu] 'belah' } \\
\text { [kəmpir] 'baring' } \\
\text { [təlu] 'daun' }\end{array}$ & $\begin{array}{l}\text { [sekunde] 'cium' } \\
\text { [yalpe] 'dua' } \\
\text { [tiyənde] 'jatuh' }\end{array}$ & \\
\hline$/ \epsilon /$ & - & $\begin{array}{c}\text { [beg:e] 'dingin' } \\
\text { [belbel] 'kotor' } \\
\text { [ber] 'tulang' }\end{array}$ & $\begin{array}{c}\text { [tub:e] 'batu' } \\
\text { [bejke] 'sejuk' } \\
\text { [telbe] 'asam' }\end{array}$ & \\
\hline /o/ & $\begin{array}{c}\text { [əkəli ] 'ibu' } \\
\text { [opiyəygu] 'gasing' }\end{array}$ & $\begin{array}{c}\text { [tobo] 'bahu' } \\
\text { [bobar] 'dagu' } \\
\text { [mollo] 'lengan' }\end{array}$ & $\begin{array}{c}\text { [palo] 'tengkuk' } \\
\text { [kiro] 'biawak' } \\
\text { [bito] 'tikus' }\end{array}$ & \\
\hline
\end{tabular}




\subsection{Pola Suku Kata Bahasa Kanum Barkari}

Berdasarkan analisis data ditemukan beberapa pola suku kata yang terdapat pada bahasa Kanum Barkari. Pola-pola tersebut sebagai berikut.

\subsubsection{Pola V}

Bentuk suku kata bahasa Kanum Barkari memiliki pola jenis ini. Pola ini hanya terdiri atas satu fonem dalam sebuah suku kata. Fonem tunggal sebagai pengisi suku kata tersebut berwujud fonem vokal.

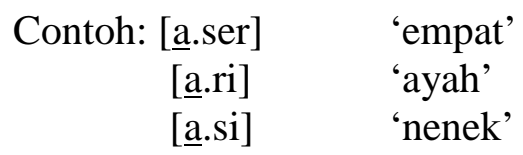

\subsubsection{Pola VK}

Bentuk suku kata bahasa Kanum Barkari memiliki pola jenis ini. Pola ini terdiri atas dua buah fonem dalam sebuah suku kata. Pola urutan fonem pengisi suku kata tersebut berupa fonem vokal pada bagian pertama dan diikuti fonem konsonan pada bagian berikutnya.

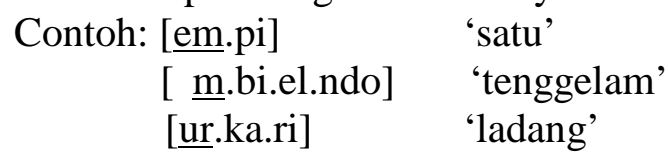

\subsubsection{Pola KV}

Bentuk suku kata bahasa Kanum Barkari memiliki pola jenis ini. Pola ini terdiri atas dua buah fonem dalam sebuah suku kata. Pola urutan fonem pengisi suku kata tersebut berupa fonem konsonan pada bagian pertama dan diikuti fonem vokal pada bagian berikutnya. Contoh: [ta.te.lu]

$$
\begin{aligned}
& \text { 'putus' } \\
& \text { 'pergi' } \\
& \text { 'raba' }
\end{aligned}
$$$$
\text { [ko.no] }
$$$$
\text { [ka.pa.yi.lo] }
$$

\subsubsection{Pola KVK}

Bentuk suku kata bahasa Kanum Barkari memiliki pola jenis ini Pola ini terdiri atas tiga buah fonem dalam sebuah suku kata. Pola urutan fonem pengisi suku kata tersebut berupa fonem konsonan pada bagian pertama diikuti fonem vokal pada bagian kedua dan ditutup dengan fonem konsonan pada bagian akhir.

Contoh: [kal]

$\begin{array}{ll}\text { [tar.ma.ru] } & \text { 'sandar' } \\ \text { [se.kar] } & \text { 'terima' }\end{array}$

\subsubsection{Pola KKV}

Bentuk suku kata bahasa Kanum Barkari memiliki pola jenis ini. Pola ini terdiri atas tiga buah fonem dalam sebuah suku kata. Pola urutan fonem pengisi suku kata tersebut berupa fonem konsonan pada bagian pertama diikuti fonem konsonan pada bagian kedua dan ditutup dengan fonem vokal pada bagian akhir.

Contoh: [nde.de.kol] 'engkau'

$\begin{array}{ll}\text { [yga.wu] } & \text { 'kulit' } \\ \text { [ygo] } & \text { 'saya' }\end{array}$

\subsubsection{Pola KKVK}

Bentuk suku kata bahasa Kanum Barkari memiliki pola jenis ini. Pola ini terdiri atas empat buah fonem dalam sebuah suku kata. Pola urutan fonem pengisi suku kata tersebut berupa fonem konsonan pada bagian pertama dan kedua, diikuti fonem vokal pada bagian ketiga, dan ditutup dengan fonem konsonan pada bagian akhir.

Contoh: [mbat]

$$
\text { [mbam.ba.yur] 'capung' }
$$

Berdasarkan hasil analisis diketahui bahwa bahasa Kanum Barkari memiliki pola suku kata campuran, yaitu suku kata terbuka dan tertutup. Adapun struktur suku kata bahasa Kanum Barkari adalah sebagai berikut.

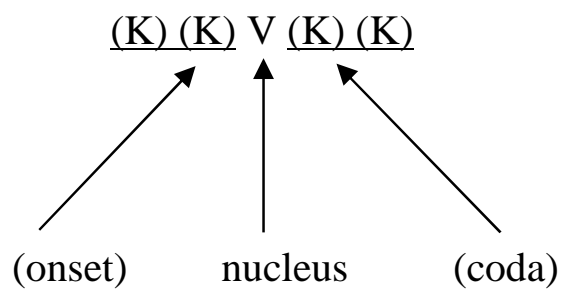




\subsection{Gugus Konsonan dan Vokal Bahasa Kanum Barkari}

Berdasarkan analisis data ditemukan beberapa gugus konsonan (kluster) dan gugus vokal (diftong) pada bahasa Kanum Barkari.

\subsubsection{Gugus Konsonan Bahasa Kanum Barkari}

Bahasa Kanum Barkari memiliki enam gugus konsonan, yaitu $/ \mathrm{mb} /, / \mathrm{nt} /, / \mathrm{ng} /$, /nd/, /kl/, dan /mp/. Contoh ketujuh gugus konsonan tersebut dapat dilihat di bawah ini.

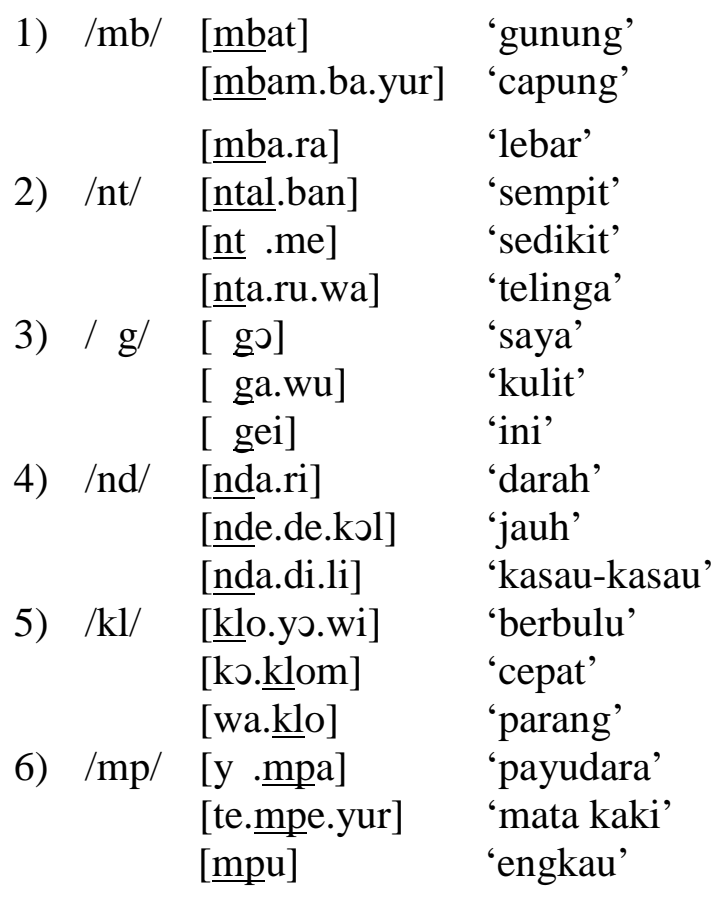

\subsubsection{Gugus Vokal (Diftong) Bahasa Kanum Barkari}

Bahasa Kanum Barkari memiliki lima gugus vokal, yaitu /ey/, /aw/, /ow/, /ew/, dan /ay/. Contoh kedua gugus vokal tersebut dapat dilihat di bawah ini.
1) /ey/ [ley] 'apa'
[mey] 'api'
[bey] 'langit-langi'
2) /aw/ [se.ma.raw] 'bakar'
[daw] 'tempat'
[tei.taw] 'belum'
3) /ow/ [tow $]$ 'perahu'

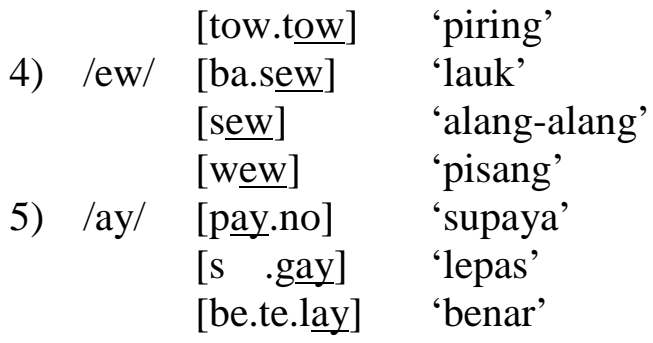

\section{Penutup}

Berdasarkan hasil analisis data yang telah dilakukan, dapat disimpulkan bahwa bahasa Kanum Barkari memiliki 16 buah fonem konsonan, yaitu fonem $/ \mathrm{p} /, / \mathrm{b} /, / \mathrm{t} /$, $/ \mathrm{d} /, / \mathrm{j} /, / \mathrm{k} /, / \mathrm{g} /, / \mathrm{m} /, / \mathrm{n} /, / \mathrm{l} /, / \mathrm{l} /, / \mathrm{s} /, / \mathrm{r} /, / \mathrm{h} /$, $/ \mathrm{w} /, / \mathrm{y} /$ dan enam (6) buah fonem vokal, yaitu fonem /a/, /i/, /u/, /e/, /€/, dan /o/. Fonem-fonem bahasa Kanum Barkari dalam kata sebagian berdistribusi lengkap dan sebagian lagi berdistribusi tidak lengkap. Tiga belas fonem yang berdistribusi lengkap, yaitu $/ \mathrm{m} /, / \mathrm{n} /, / \mathrm{y} /$, /l/, /s/, /r/, /w/, /a/, /i/, /u/, /e/, dan /o/; tujuh fonem berdistribusi di awal dan tengah kata, yaitu /p/, /b/, /t/, /j/, /k/, /g/, dan $/ y /$; satu fonem berdistribusi di tengah dan akhir kata, yaitu /€/; dan hanya satu fonem yang berdistribusi di akhir kata, yaitu /h/. Bahasa Kanum Barkari juga terdapat enam buah gugus konsonan, yaitu /mb/, /nt/, /ng/, /nd/, /kl/, dan $/ \mathrm{mp} /$ serta lima buah gugus vokal, yaitu /ey/, /aw/, /ow/, /ew/, dan /ay/. Selain itu, juga dapat diketahui bahwa bahasa Kanum Barkari memiliki pola suku kata dengan struktur pola V, VK, KV, KVK, KKV, dan KKVK.

Berdasarkan data, walaupun dalam bahasa Kanum Barkari terdapat unsurunsur suprasegmental berupa tekanan, nada, dan durasi, akan tetapi tidak terdapat unsur suprasegmental yang distingtif atau yang membedakan makna. Oleh sebab itu, dapat disimpulkan bahwa dalam bahasa Kanum Barkari tidak terdapat fonem suprasegmental. Mengenai unsur suprasegmental yang berupa durasi selalu jatuh pada suku terbuka yang dibunyikan panjang. 
Daftar Pustaka

Alwi, Hasan dkk. 2000. Tata Bahasa

Baku Bahasa Indonesia. Jakarta: Balai Pustaka.

Bloomfield, L. 1933. Language. London: George Allen \& Unwin.

Chaer, Abdul. 2009. Fonologi Bahasa Indonesia. Jakarta: Rineka Cipta.

Hartman, R.R.K. and F.C. Stork. 1972. Dictionary of Language and Lingusitic. Applied Science Published, Ltd. England.

Kridalaksana, Harimurti. 2008. Kamus Linguistik. Jakarta: Gramedia.

Lapoliwa, Hans. 1980. Analisis Fonologi. Jakarta: Pusat Pembinaan dan Pengembangan Bahasa.

Muslich, Masnur. 2010. Fonologi Bahasa Indonesia: Tinjauan
Deskriptif Sistem Bunyi Bahasa Indonesia. Jakarta: Bumi Aksara.

Samsuri. 1982. Analisis Bahasa. Jakarta: Erlangga.

Sudaryanto.1993. Metode dan Aneka Teknik Analisis Bahasa: Pengantar Penelitian Wahana Kebudayaan Secara Linguistis. Yogyakarta: Duta Wacana University Press.

Suharyanto. 2006. "Fonologi Bahasa Kayu Pulo" dalam Jurnal Kibas Cenderawasih Volume 2 Nomor 2 Oktober 2006. Jayapura: Balai Bahasa Jayapura.

Summer Institute of Linguistic. 2006. Bahasa-Bahasa di Indonesia. Jakarta: Summer Institute of Linguistic. 